\title{
Mycorrhizal Colonization Increases Herbicide Toxicity in Apple
}

\author{
C. Hamel ${ }^{1}$ \\ Service de phytotechnie de St-Hyacinthe, Station de St-Bruno, 335 rang des vingt-cinq, St-Bruno-de- \\ Montarville, Québec J3V 4P6, Canada \\ F. Morin \\ Plant Science Department, Macdonald campus of McGill University, 2111 Lakeshore Road, Ste-Anne-de- \\ Bellevue, Québec H9X 1CO, Canada
}

\author{
A. Fortin \\ Institut de recherche en biologie végétale, 4101 Sherbrooke est, Montréal, Québec H1X 2B2, Canada
}

R.L. Granger

Station de recherche, Agriculture Canada, 430 boul. Goin, St-Jean-sur-Richelieu, Québec J3B 6Z8, Canada

\begin{abstract}
D.L. Smith
Plant Science Department, Macdonald campus of McGill University, 2111 Lakeshore Road, Ste-Anne-deBellevue, Québec, H9X 1C0, Canada
\end{abstract}

Additional index words. Malus domestica, Glomus versiforme, G. intraradices, simazine, paraquat, dichlobenil, herbicides, pesticides, endomycorrhizae

\begin{abstract}
Herbicides are increasingly used in orchards. Since apple trees strongly depend on mycorrhizae, the effects of three commonly used herbicides on the host plant and endophyte were examined. Symbiosis between tissue-cultured P16 apple rootstocks and Glomus versiforme (Karsten) Berch was established under greenhouse conditions. Simazine (1, 2, 10, and $20 \mu \mathrm{g}$ a.i./g), dichlobenil $(1,5,10$, and $25 \mu \mathrm{g}$ a.i./g), paraquat $(0.5,1,10$, and $100 \mu \mathrm{g}$ a.i./g), or water was applied to mycorrhizal and nonmycorrhizal plants as a soil drench. The response of mycorrhizal plants to herbicide was greater, and the relative elongation rate was more sharply reduced in mycorrhizal $(76 \%)$ than in nonmycorrhizal plants $(33 \%)$. Six weeks after herbicide application, dry mass reduction due to herbicides was similar (39\% and $36 \%)$ for mycorrhizal and nonmycorrhizal plant shoots, respectively, while root dry mass reduction was larger for mycorrhizal $(63 \%)$ than nonmycorrhizal plants $(46 \%)$. None of the herbicide treatments affected root colonization. However, an in vitro hyphal elongation test with $G$. intraradices Schenck \& Smith and herbicide-amended $(0,1,10,100$, and $1000 \mu \mathrm{g}$ a.i./g) gellan gum solidified water showed that either dichlobenil or paraquat, even at the lowest concentrations, could significantly reduce hyphal elongation. Simazine did not affect hyphal elongation in vitro, a result suggesting that improved absorption capacity of mycorrhizae explains, at least in part, the increased phytotoxicity of some herbicides. It was found that plant mortality was higher among mycorrhizal than nonmycorrhizal apple trees for all herbicide treatments. The increased $\mathrm{CO}_{2}$ assimilation rates of dichlobenil-treated mycorrhizal plants contrasted with the decreased rates of control plants measured 1 week after dichlobenil treatment. This indicates a physiological interaction between mycorrhizal colonization and dichlobenil in the toxic response of apple plants. Chemical names used: 2-chloro-4,6-bis-ethylamino-s-triazine (simazine), 2,6-dichlorobenzonitrile (dichlobenil), 1,1'-dimethyl-4,4'bipyridinium (paraquat).
\end{abstract}

An intimate relationship between vascular plants and arbuscular mycorrhizal fungi has developed during the course of 400 million years of coevolution (Simon et al., 1993). Arbuscular endophytes are widely distributed in virtually all soils (Mosse, 1978), and many plants form arbuscular mycorrhizae (Harley and Smith, 1983). Apple (Malus domestica Borkh) is no exception. Since early investigations showing apple to be mycorrhizal (Boulet, 1910), a wide range of mycorrhizal fungal species have been found in association with Malus (Dalpé et al., 1986; Miller et al., 1985).

As in other plants, arbuscular mycorrhizae of apple ensures uptake of nutrients, particularly $\mathrm{P}, \mathrm{Zn}$, and $\mathrm{Cu}$ (Benson and Covey,

Received for publication 30 Aug. 1993. Accepted for publication 15 Mar. 1994. This project was supported by a grant from Conseil de recherche en pêche et agroalimentaire du Québec. F. Morin and C. Hamel were supported by fellowships from the Natural Sciences and Engineering Research Council. We gratefully acknowledge Nicolas Maresca for editing the manuscript. The cost of publishing this paper was defrayed in part by the payment of page charges. Under postal regulations, this paper therefore must be hereby marked advertisement solely to indicate this fact. ${ }^{1}$ To whom reprint requests should be addressed.
1976; Covey et al., 1981; Gnekow and Marschner, 1989), and improves resistance to drought (Runjin, 1989) and diseases caused by soilborne pathogens (Dehne, 1982). Apple strongly depends on mycorrhizae (Covey et al., 1981; Geddeda et al., 1984), and growth is enhanced even at high soil P levels (Morin et al., 1994).

Herbicide application is common practice in orchard management, especially with dwarf trees, and some herbicides can significantly influence arbuscular fungi and mycorrhiza formation (Trappe et al., 1984) (R.L. Granger personal communication). Some herbicides affect arbuscular fungi either directly or by affecting the host plants (Garcia-Romera and Ocampo, 1988). One such herbicide, simazine, actually induced mycorrhiza formation on Chenopodium quinona, an otherwise nonmycorrhizal species, and reduced plant growth (Schwab et al., 1982). Most of the time, however, herbicides have either no effect (Burpee and Cole, 1978; Ocampo and Barea, 1982; Smith et al., 1981; South, 1981) or negatively affect mycorrhizal fungi (Nemec and Tucker, 1983; Pope and Holt, 1981; Sieverding and Leihner, 1984).

Paraquat, a nonselective herbicide, is currently recommended 
for application in orchards the year of planting and in subsequent years. The residual herbicides simazine and dichlobenil are recommended for use the planting year. We present the results of an experiment to test the effect of increasing rates of paraquat, simazine, and dichlobenil on mycorrhizal apple rootstock and on in vitro mycelium elongation from spore clusters of a Glomus sp.

\section{Materials and Methods}

Pot experiment. A $2 \times 13$ factorial experiment was designed during the summer under greenhouse conditions. The temperature ranged from 18 to $30 \mathrm{C}$ on very warm days. A 16-h day length was kept constant using high-pressure sodium lamps.

Tissue-cultured P16 apple rootstocks were planted in 4-liter pots containing a sandy loam soil taken from the top $20 \mathrm{~cm}$ of the soil profile in an apple rootstock nursery at St-Jean-Baptiste-deRouville, Québec. The soil contained 2.2\% organic matter and the fertility status at the beginning of the experiment was $\mathrm{pH}=7.3,644$ $\mathrm{kg}$ of P-Bray 1/ha, $2380 \mathrm{~kg}$ of K/ha, $3090 \mathrm{~kg}$ of Ca/ha, $697 \mathrm{~kg}$ of $\mathrm{Mg} / \mathrm{ha}, 1.6 \mu \mathrm{g} \cdot \mathrm{g}^{-1} \mathrm{~B}, 2.2 \mu \mathrm{g} \cdot \mathrm{g}^{-1} \mathrm{Cu}, 360.1 \mu \mathrm{g} \cdot \mathrm{g}^{-1} \mathrm{Fe}, 34.8 \mu \mathrm{g} \cdot \mathrm{g}^{-1} \mathrm{Mn}$, and $12.8 \mu \mathrm{g} \cdot \mathrm{g}^{-1} \mathrm{Zn}$. Soil was passed through a $5-\mathrm{mm}$ sieve and steam-pasteurized at $72 \mathrm{C}$ for $5 \mathrm{~h}$. To alleviate the problem of soil structure loss due to manipulation, the substrate was amended with grade 16 silica sand [1 sand : 3 soil $(\mathrm{v} / \mathrm{v})]$.

Half of the plants was inoculated with $1 \mathrm{~g}$ (fresh mass) of corn roots colonized by $G$. versiforme and cut into 1-cm fragments. Inoculum was placed at the bottom of the transplanting holes immediately before planting. Control plants received $1 \mathrm{~g}$ of autoclaved inoculum. To account for the effects of nonmycorrhizal organisms possibly carried in the inoculum, control plants also received $5 \mathrm{ml}$ of filtered (Whatman GF/D, 2.7- $\mu \mathrm{m}$ ) washings of the mycorrhizal inoculum.

Symbiosis was allowed to establish for 8 weeks before applying the herbicides. The length of this period had been determined based on the results of a previous experiment (Morin et al., 1994), and examining the root systems of extra plants confirmed that the inoculation was successful. Mycorrhizal and control plants were treated with simazine at 1,2,10, and $20 \mu \mathrm{g}$ a.i./g oven-dried soil, dichlobenil at $1,5,10$, and $25 \mu \mathrm{g}$ a.i./g oven-dried soil, paraquat at $0.5,1,10$, and $100 \mu \mathrm{g}$ a.i./g oven-dried soil, or water. Herbicide concentrations had been selected to include the recommended rates $(2 \mu \mathrm{g}$ a.i. simazine, $5 \mu \mathrm{g}$ a.i. dichlobenil, and $0.5 \mu \mathrm{g}$ a.i. paraquat/g soil) and toxicity levels reported in the literature (Dvorak, 1968; Hogue and Neilsen, 1988; Lord et al., 1972; Lord and Greene, 1975; Robinson and Lord, 1970). Herbicides were prepared in $500 \mathrm{ml}$ of distilled water and applied as a soil drench to the designated pots. The volume of the suspensions (or solutions for paraquat) was too small to allow the herbicide to drain from the pots, but the herbicides were not translocated throughout the whole soil volume. Because of their formulation, simazine (wettable powder) and dichlobenil (granules) were probably more concentrated in the top layer of the soil than paraquat, which forms a solution in water. All treatments were replicated in four blocks.

Plants were always watered according to their needs, given just enough water to avoid drainage from the pots. All plants were fertilized once, 6 weeks after transplantation, with a phosphatefree nutrient solution.

Measurements. One week after herbicide treatment, plant photosynthetic rates were measured using a photosynthesis meter (LI6200; LI-COR, Lincoln, Neb.). The photosynthetic activity of the penultimate, fully expanded, young leaf of each plant was recorded in duplicate and averaged.

Plant height was measured every other week after transplant- ing. Six weeks after herbicide treatment, mortality was recorded, and all plants (including dead plants) were harvested. Plant dry mass was recorded after drying at $70 \mathrm{C}$ for 2 days, and percentage of root colonization was measured using the grid-intersect method (Giovanetti and Mosse, 1980) after staining root samples with acid fuchsin (Brundrett et al., 1984).

In vitro hyphal elongation test. Spore clusters (for 20 to 30 spores) of in vitro-cultured (Bécard and Fortin, 1988) G. intraradices were deposited in Petri plates on sterile gellan gum solidified water amended with $0,1,10,100$, and $1000 \mu \mathrm{g}$ a.i./g of simazine, dichlobenil, or paraquat. Glomus intraradices was chosen for this test because it could be grown on root culture, unlike G. versiforme, and because it gave good results with apple in a previous experiment (Morin et al., 1994).

Treatments were applied to the petri plates as follows. Herbicides were diluted in sterile water to the designated concentrations. Paraquat was dissolved and millipore-filtrated $(0.22 \mu \mathrm{m})$, while dichlobenil and simazine were suspended without filtration (to avoid losing the active ingredients) and kept under agitation in sterile water under a laminar flow hood before use. Then, $1 \mathrm{ml}$ of the different concentrations of each herbicide was spread in petri plates over $20 \mathrm{ml}$ of solidified water $(0.4 \%$ Gel-Gro and $0.05 \%$ $\mathrm{MgSO}_{4} \cdot 7 \mathrm{H}_{2} \mathrm{O}$ ). Petri plates were incubated at $28 \mathrm{C}$ for 7 days.

Hyphal length was measured by the line-intersect method (Tennant, 1975) under a dissecting microscope bearing a grid (10 $\times 101$-mm squares) in one eye piece. The highest concentration of simazine and dichlobenil interfered with measurement. The mycelium could not be clearly seen, so its length was not measured.

Statistical analysis. Since mycorrhizal and nonmycorrhizal plant dry mass differed, dry mass reduction was calculated as the percentage of dry mass reduction of herbicide-treated plants relative to the respective (mycorrhizal or nonmycorrhizal) nontreated control. Similarly, we considered the relative elongation rates (i.e., elongation per week per initial height) in our analysis.

Data were subjected to analysis of variance using SAS's general linear model (GLM) procedure (SAS Institute, 1989). Percentages were arcsin-transformed before analysis (Steel and Torrie, 1980). Orthogonal polynomial contrasts were used to characterize plant responses to herbicides (Steel and Torrie, 1980). Duncan's multiple range test was used to compare mycorrhizal treatment means (Steel and Torrie, 1980).

\section{Results}

Glomus versiforme colonized apple rootstocks effectively. On average, $92 \%$ of inoculated plant root systems contained mycorrhizal fungi at harvest (data not shown), while no colonization was found in nonmycorrhizal plant roots. After a lag phase of 5 weeks, the mycorrhizal fungus increased plant growth rates (Fig. 1). From the sixth week on, the mycorrhizal apple rootstocks were significantly taller than the nonmycorrhizal controls.

Relative plant elongation rate of mycorrhizal plants was reduced from $0.72 \mathrm{~cm} /$ week per $\mathrm{cm}$ of plant before herbicide application to $0.17 \mathrm{~cm} /$ week per $\mathrm{cm}$ of plant 4 weeks after herbicide application, while that of nonmycorrhizal apple had dropped from 0.09 to $0.06 \mathrm{~cm} /$ week per $\mathrm{cm}$ of plant (data not shown). The increased susceptibility of mycorrhizal apple rootstocks was independent of the level and type of herbicide used, as indicated by the absence of interaction between inoculation and herbicide treatments.

At harvest, plant shoot and root biomass were significantly decreased by almost all herbicide treatments (Table 1). Reduced mycorrhizal and nonmycorrhizal shoot dry mass, due to herbicide 


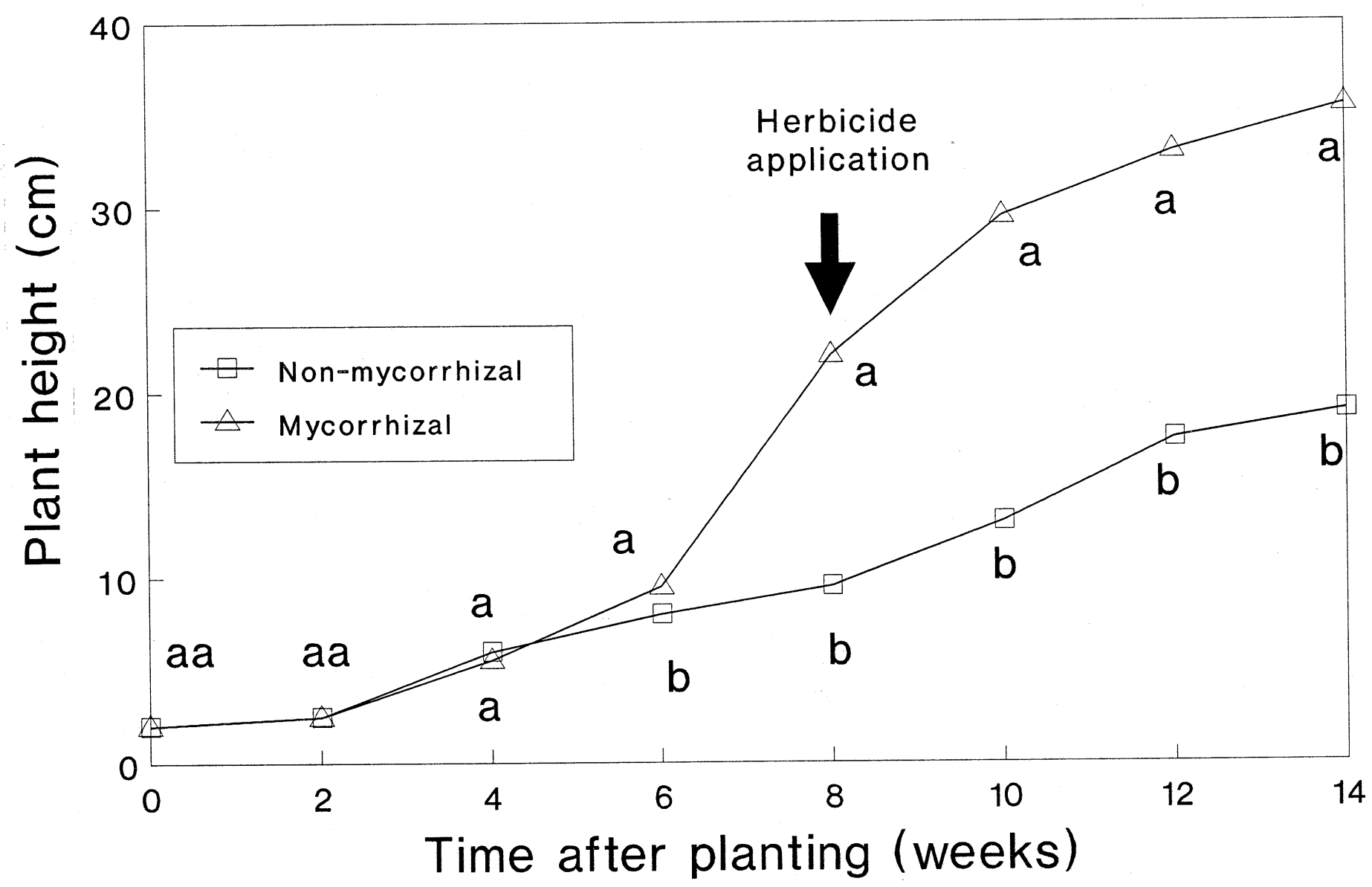

Fig. 1. Growth of mycorrhizal and nonmycorrhizal P16 apple rootstock before and after treatment (simazine at 1, 2, 10, and $20 \mu \mathrm{g}$ a.i./g; dichlobenil at 1, 5, 10 , and 25 $\mu \mathrm{g}$ a.i./g; paraquat at $0.5,1,10$, and $100 \mu \mathrm{g}$ a.i./g; and water applied as a soil drench). The arrow indicates application time. Mean separation within weeks $P<0.05$ $(\mathrm{n}=52)$ using the general linear models procedure.

Table 1. Average P16 apple rootstock shoot and root dry mass and percentage of dry mass reduction relative to controls 6 weeks after applying the herbicides dichlobenil, paraquat, and simazine.

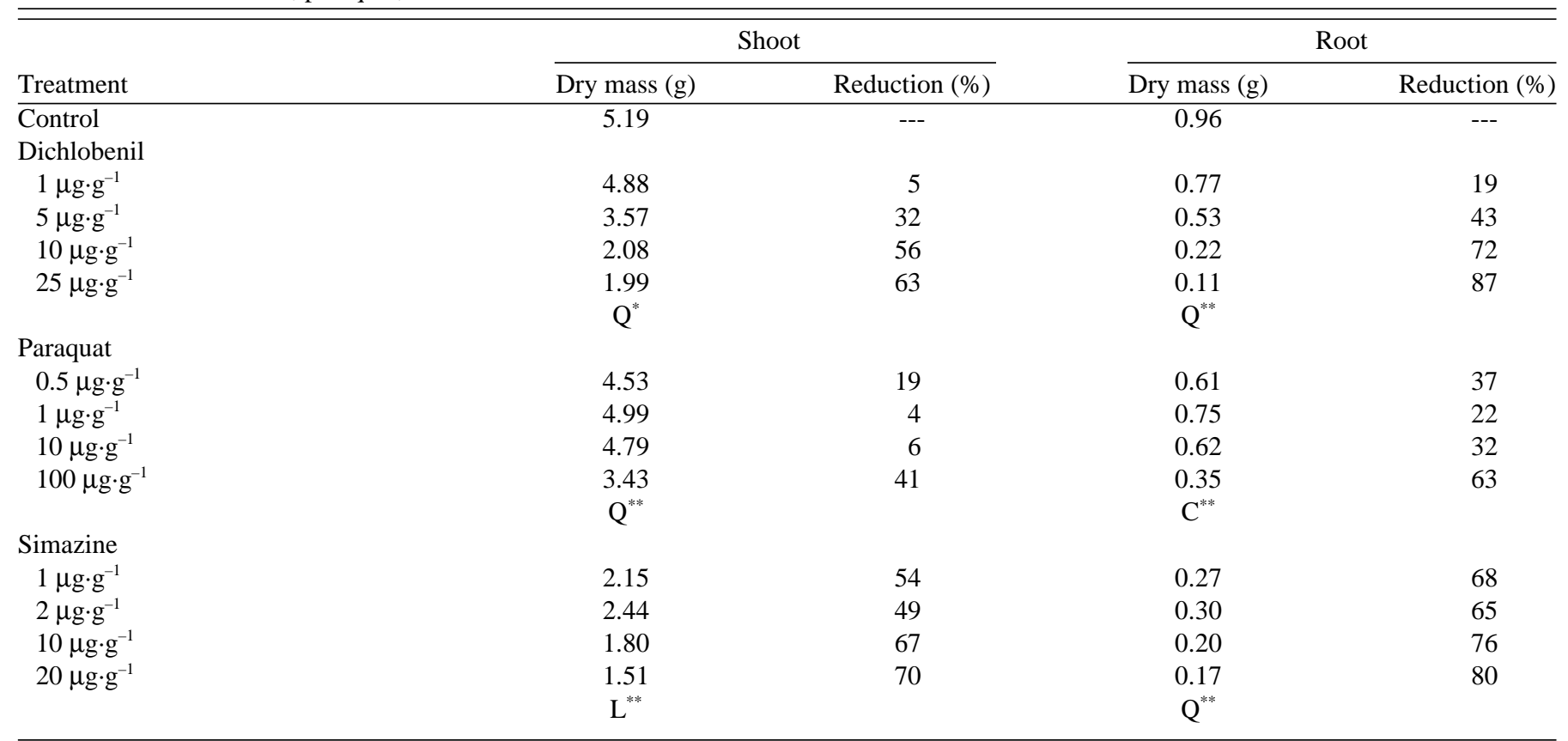

\footnotetext{
${ }^{*, * *}$ Significant at $P=0.05$ or 0.01 , respectively; orthogonal polynomial contrast; $\mathrm{L}=$ linear, $\mathrm{Q}=$ quadratic.
} 
Table 2. Average shoot and root dry mass for treated and nontreated (control) P16 apple rootstock and percentages of dry mass reduction 6 weeks after herbicide application.

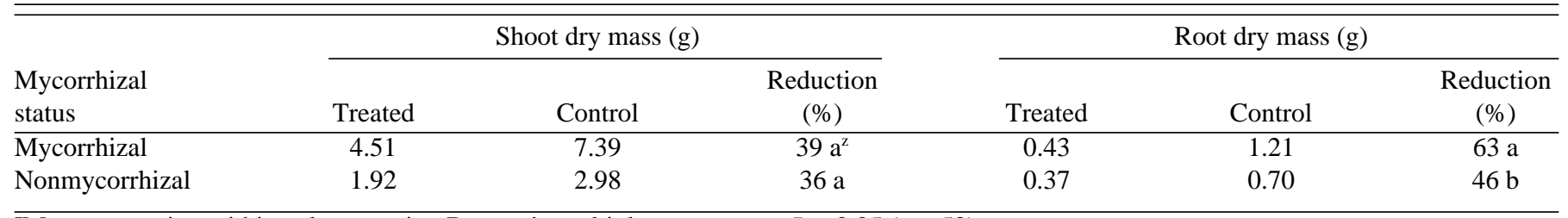

${ }^{\mathrm{z}}$ Mean separation within columns using Duncan's multiple range test at $P=0.05(\mathrm{n}=52)$.

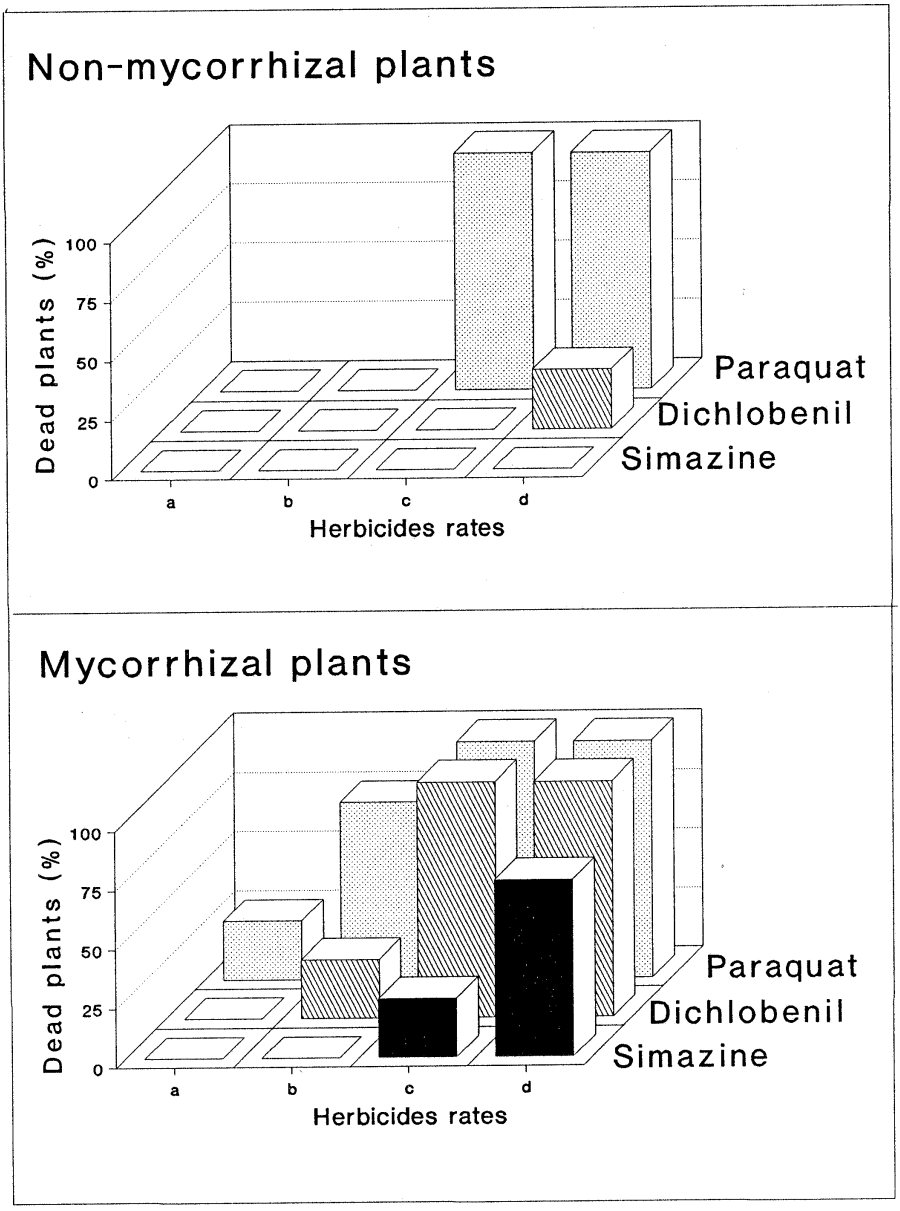

Fig. 2. Effect of the mycorrhizal status on P16 apple rootstock mortality 6 weeks after application of (a-d) simazine at 1,2,10, and $20 \mu \mathrm{g}$ a.i./g; dichlobenil at 1 , 5,10 , and $25 \mu \mathrm{g}$ a.i./g; or paraquat at $0.5,1,10$, and $100 \mu \mathrm{g}$ a.i./g applied as a soil drench 8 weeks after inoculating the plants. Bars represent means of four plants.

Table 3. Average percent hyphal length reduction from Glomus intraradices spore clusters placed on herbicide-amended solidified water after 7 days, relative to nontreated controls. ${ }^{\mathrm{z}}$

\begin{tabular}{lccc}
\hline \hline Concn & \multicolumn{3}{c}{ Herbicide $(\%)$} \\
\cline { 2 - 4 }$\left(\mu \mathrm{g} \cdot \mathrm{g}^{-1}\right)$ & Simazine & Dichlobenil & Paraquat \\
\hline 0 & 0 & 0 & 0 \\
1 & 12 & 47 & 57 \\
10 & 14 & 99 & 71 \\
100 & 11 & 100 & 100 \\
1000 & ND & ND & 100 \\
& & $Q^{* *}$ & $Q^{* * *}$
\end{tabular}

${ }^{\mathrm{z}}$ Data was arcsin-transformed before analysis.

**Significant at $P=0.01$, orthogonal polynomial contrast; $\mathrm{Q}=$ quadratic. applications, was similar (Table 2). However, reduced mycorrhizal root dry mass in response to herbicide treatments was more pronounced than that of nonmycorrhizal roots, and plant mortality was much greater among mycorrhizal than nonmycorrhizal plants (Fig. 2). No control plants were killed by simazine, even at $20 \mu \mathrm{g}$ a.i./g of dry soil.

Over all treatments, $23.9 \mathrm{~mm}$ of hyphae emerged after 7 days from spore clusters deposited on nonamended gellan gum solidified water (data not shown). Simazine did not affect hyphal growth at any level applied (Table 3). However, as little as $1 \mu \mathrm{g} \cdot \mathrm{g}^{-1}$ of dichlobenil or paraquat significantly reduced the growth of $G$. intraradices in vitro. Although dichlobenil and paraquat reduced fungal growth in vitro, they did not significantly affect the percentage of root colonization by the mycorrhizal fungus in the greenhouse experiment (data not shown).

Simazine and paraquat significantly reduced $(P<0.05)$ the photosynthetic rates of mycorrhizal and nonmycorrhizal plants (data not shown). However, an herbicide $\times$ inoculation interaction $(P=0.018)$ indicates that the fungus changed the plants' response to dichlobenil: increasing rates of dichlobenil applied to mycorrhizal plants increased plant photosynthetic rates relative to that of the controls, while increasing rates of dichlobenil on nonmycorrhizal plants reduced it (Fig. 3).

\section{Discussion}

Few studies have compared the effects of herbicides on mycorrhizal and nonmycorrhizal plants. Pope and Holt (1981) found reduced growth and $\mathrm{P}$ uptake by white ash (Fraxinus americana L.) grown in soil amended with paraquat only in mycorrhizal plants. They also measured a direct detrimental effect of 1.33 $\mu \mathrm{g} \cdot \mathrm{g}^{-1}$ of paraquat on the production of external mycelium and spores by the fungus and on colonization of ash roots, a result suggesting that paraquat affects plant development through its effect on the fungus.

In contrast to Pope and Holt's experiment, we studied the effect of herbicides applied after mycorrhizae establishment. Similarly to Pope and Holt's results, we found an increase in the toxic response of P16 apple rootstocks treated with simazine, paraquat, or dichlobenil when plants were mycorrhizal, but found no significant effect of the herbicides on the percent root colonization, although the size of the mycorrhizal root systems was reduced. In addition, our in vitro hyphal elongation test showed no effect due to $100 \mu \mathrm{g}$ of simazine on $G$. intraradices hyphal elongation. Still, at the highest rate, $75 \%$ of simazine-treated mycorrhizal plants died, while no control plants died.

The death of plants concurrent to a lack effect on root colonization and on hyphal elongation suggest that the herbicides tested are more toxic to apple than to mycorrhizal fungi and that the $G$. versiforme increased further the phytoxicity of the chemicals by improving their uptake by apple rootstocks. This hypothesis is supported by recent findings of Nelson and Khan (1992), who 


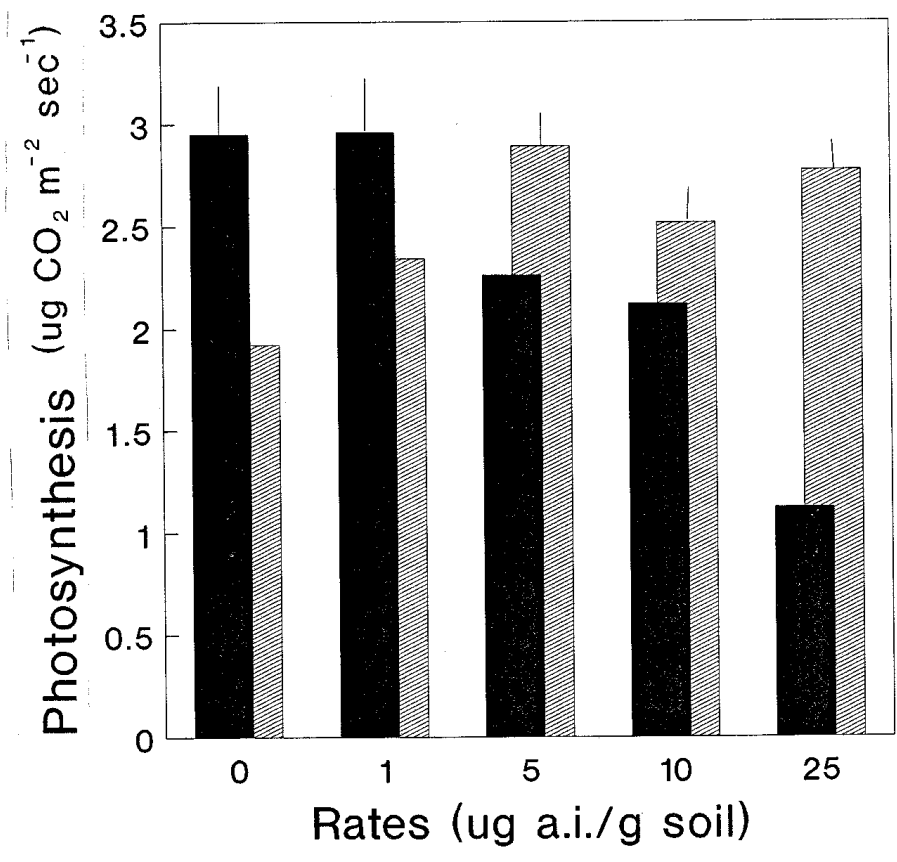

Fig. 3. Contrasting effects of dichlobenil relative to water-treated controls on the photosynthetic rates of mycorrhizal and nonmycorrhizal P16 apple rootstock. Carbon dioxide assimilation rates were measured on the first uppermost fully expanded leaf of each plant 1 week after applying the herbicide as a soil drench. Vertical bars indicate $\mathrm{SE}, \mathrm{n}=4$. Solid $\mathrm{bar}=$ nonmycorrhizal, hatched $\mathrm{bar}=$ mycorrhizal.

demonstrated, using compartmentalized containers and ${ }^{14} \mathrm{C}-\mathrm{la}-$ belled atrazine, that mycorrhizal hyphae were able to remove atrazine from soil and transfer it to plants. This observation could also apply to other chemicals.

Increases in carbohydrate exudation by Chenopodium quinona, when treated weekly with sublethal doses of simazine, is hypothesized to stimulate mycorrhizae formation on this otherwise nonmycorrhizal plant (Schwab et al., 1982). In a later study, Nemec and Tucker (1983) observed that Citrus seeded in soil amended with $1.2 \mu \mathrm{g} \cdot \mathrm{g}^{-1}$ simazine developed a significantly higher percentage of root colonization. They explained their results either by inhibited competing organisms or, in agreement with Schwab et al. (1982), by increased root exudation.

In the same study, amending the soil with the highest level of simazine $\left(7.1 \mu \mathrm{g} \cdot \mathrm{g}^{-1}\right)$ resulted in reduced mycorrhizal colonization of Citrus from 64\% to $11 \%$ (Nemec and Tucker, 1983). Similarly, paraquat reduced the development of $G$. fasciculatum and mycorrhizal colonization of ash trees (Pope and Holt, 1981).

Our results do not corroborate these previous studies. Although dichlobenil and paraquat may harm mycorrhizal fungi, as shown by the adverse effect of these herbicides on fungal growth in vitro, we did not measure any detrimental effect on root colonization of dead or living apple rootstocks after applying dichlobenil, paraquat, or simazine. We measured, however, reduced root growth, which should have reduced the length of colonized roots and may have reduced external mycelium length. It must also be emphasized that the 6-week period between herbicide application and plant harvest was a relatively short time for an effect to develop.

The absence of a negative impact of simazine applied even at very high levels on in vitro elongating mycorrhizal hyphae is not surprising. Although after being taken up by roots simazine interferes with a variety of plant biochemical processes including phytosynthesis, plant growth regulation, and nitrogen and nucleic acid metabolism (Esser et al. 1975), the chemical seems harmless to at least some fungi. When simazine was applied at a rate of 5 $\mu \mathrm{g} \cdot \mathrm{g}^{-1}$, Aspergillus fumigatus was able to metabolize the herbicide as a $\mathrm{C}$ source, while another study has shown that fungal populations of a sandy loam soil were slightly stimulated at concentrations of 2.5 to $10 \mu \mathrm{g} \cdot \mathrm{g}^{-1}$ (Esser et al., 1975).

Many herbicides do not affect some mycorrhizae, including triallate, diuron, and trifluralin on wheat (Smith et al., 1981); chlorpropham, sulfallate, and phenmidian on wheat and alfalfa (Ocampo and Barea, 1982); bromacil, diuron, and trifluralin on Citrus (Nemec and Tucker, 1983); alachlor and trifluralin on soybean (Burpee and Cole, 1978); and oxadiazon and trifluralin on sweetgum (South, 1981). In contrast, Sieverding and Leihner (1984) observed that oxadiazon and oxifluorfen decreased cassava root colonization and fungal spore number. Also, Garcia-Romera and Ocampo (1988) found variation in herbicide tolerance among mycorrhizal fungus species.

The opposite effects of dichlobenil on the photosynthetic rates of mycorrhizal and nonmycorrhizal plants 1 week after application are difficult to explain. We know that dichlobenil is absorbed from soil by the roots and translocated to leaves (Humburg et al., 1989). Dichlobenil is a powerful inhibitor of germination and of actively dividing meristems and acts primarily on growing points and root tips. However, studies with Chlorella and Scenedesmus revealed no effects of dichlobenil on respiration or photosynthesis (Humburg et al., 1989).

Physiological changes induced by mycorrhizal colonization could be involved in the interaction between colonization and dichlobenil application, as suggested by the work of Nelson and Khan (1992). They found that the symbiosis could change the allocation and metabolism of a herbicide, as shown by differences in the proportion of bound and methanol extractable ${ }^{14} \mathrm{C}$-labelled $s$-triazine in corn.

A better knowledge of the impact on mycorrhizae of various herbicides used in crop production should facilitate the development of sound agricultural strategies. This is particularly important for managing mycorrhizal-dependent crops such as apple.

\section{Literature Cited}

Bécard, G. and J.A. Fortin. 1988. Early events of vesicular-arbuscular mycorrhiza formation on Ri T-DNA transformed roots. New Phytol. 108:211-218.

Benson, N.T. and R.P. Covey. 1976. Response of apple seedlings to zinc fertilization and mycorrhizal inoculation. HortScience 11:252-253.

Boulet, M.V. 1910. Sur les mycorhizes endotrophes de quelques arbres fruitiers. C.R. Hebd. Seances Acad. Sci. Ser. D 150:1190-1192.

Brundrett, M., Y. Piché, and R.L. Peterson. 1984. A new method for observing the morphology of vesicular-arbuscular mycorrhizae. Can. J. Bot. 62:2128-2134.

Burpee, L.L. and H. Cole. 1978. The influence of alachlor, trifluralin and diazinon on the development of endogenous mycorrhizae in soybeans. Bul. Environ. Contamination Toxicol. 19:191-197.

Covey, R.P., B.L. Koch, and H.J. Larsen. 1981. Influence of vesicular arbuscular mycorrhizae on the growth of apple and corn in lowphosphorus soil. Phytopathology 71:712-715.

Dalpé, Y., R.L. Granger, and V. Furlan. 1986. Abondance relative et diversité des Endogonacées dans un sol de verger du Québec. Can. J. Bot. 64:912-917.

Dehne, J. 1982. Interaction between vesicular-arbuscular mycorrhizal fungi and plant pathogens. Phytopathology 72:1115-1118.

Dvorak, J. 1968. The influence of simazine on shoot and root growth of apples and plums. Weed Res. 8:8-13.

Esser, H.O., G. Dupuis, E. Ebert, G.J. Marco, and C. Vogel. 1975. S Triazines, p. 129-208. In: P.C. Keraney and D.D. Kaufman (eds.). Herbicides: Chemistry, degradation, and mode of action. 2nd ed. Marcel 
Dekker, New York.

Garcia-Romera, I. and J.A. Ocampo. 1988. Effect of the herbicide MCPA on VA mycorrhizal infection and growth of Pisum sativum. Zeit. Pflanz. Bodenkd. 151:225-228.

Geddeda, Y.I., J.M. Trappe, and R.L. Stebbins. 1984. Effects of vesicular arbuscular mycorrhizae and phosphorus on apple seedlings. J. Amer. Soc. Hort. Sci. 109:24-27.

Giovanetti, M. and B. Mosse. 1980. An evaluation of techniques for measuring vesicular-arbuscular mycorrhizal infection in roots. New Phytol. 84:489-500.

Gnekow, M.A. and H. Marschner. 1989. Role of VA-mycorrhiza in growth and mineral nutrition of apple (Malus pumila var. domestica) rootstock cuttings. Plant and Soil 119:285-293.

Harley, J.L. and S.E. Smith. 1983. Mycorrhizal symbiosis. Academic Press, New York.

Hogue, E.J. and G.H. Neilsen. 1988. Effects of excessive annual applications of terbacil, diuron, simazine and dichlobenil on vigor, yield and cation nutrition of young apple trees. Can. J. Plant Sci. 68:843-850.

Humburg, N.E., E.R. Hill, W.J. McAvoy, S.R. Colby, R.G. Lyn, L.M. Kitchen, and R. Prasad. 1989. Herbicide handbook of the Weed Science Society of America. 6th ed. Weed Sci. Soc. Amer., Champaign, Ill.

Lord, W.J., R.A. Damon, and D.E. Robinson. 1972. Phytotoxicity of soil incorporated 2,6-dichlorobenzonitrile to clonal apple rootstocks. J. Amer. Soc. Hort. Sci. 97:390-392.

Lord, W.J. and D.W. Green. 1975. Apple tree response to dichlobenil. HortScience 10:395-396.

Miller, D.D., P.A. Domoto, and C. Walker. 1985. Mycorrhizal fungi at eighteen apple rootstock plantings in the United States. New Phytol. 100:379-391.

Morin, F., C. Hamel, J.A. Fortin, R.L. Granger, and D.L. Smith. 1994. Apple rootstock response to vesicular-arbuscular mycorrhizal fungi in a high phosphorus soil. J. Amer. Soc. Hort. Sci. 119:578-583.

Mosse, B. 1978. Mycorrhiza and plant growth, p. 269-297. In: A.J.J. Ferysen and J.W. Waldendorp (eds.). Structure and funtionning of plant populations. North Holland Publishing Co., Amsterdam.

Nelson, S.D. and S.U. Khan. 1992. Uptake of atrazine by hyphae of Glomus vesicular-arbuscular mycorrhizae and root systems of corn (Zea mays L.). Weed Sci. 40:161-170.
Nemec, S. and D. Tucker. 1983. Effects of herbicides on endomycorrhizal fungi in Florida citrus (Citrus spp.) soils. Weed Sci. 31:427-431.

Ocampo, J.A. and J.M. Barea. 1982. Depressed metabolic activity of VA mycorrhizal fungi by photosynthesis inhibitor herbicides, p. 267-270. In: S. Gianinazzi, V. Gianinazzi-Pearson, and A. Trouvelot (eds.). Mycorrhizae, an integral part of plants: Biology and perspectives for their use. INRA Publ. Colloq., France.

Pope, P.E. and H.A. Holt. 1981. Paraquat influences development and efficacy of the mycorrhizal fungus Glomus fasciculatus. Can. J. Bot. 59:518-521.

Robinson, D.E. and W.J. Lord. 1970. Response of McIntosh apple trees to soil incorporated simazine. J. Amer. Soc. Hort. Sci. 95:195-199.

Runjin, L. 1989. Effects of vesicular-arbuscular mycorrhizas and phosphorus on water status and growth of apple. J. Plant. Nutr. 12:997-1017. SAS Institute. 1989. SAS/STAT user's guide. version 6. 4th ed. SAS Inst., Cary, N.C.

Schwab, S.M., E.L. Johnson, and J.A. Menge. 1982. Influence of simazine on formation of vesicular-arbuscular mycorrhizae in Chenopodium quinona Willd. Plant and Soil 64:283-287.

Sieverding, E. and D.E. Leihner. 1984. Effect of herbicides on population dynamics of VA-mycorrhziae with cassava. Angew. Botanik 58:283294.

Simon, L., J. Bousquet, R.C. Lévesque, and M. Lalonde. 1993. Origin and diversification of endomycorrhizal fungi and coincidence with vascular land plants. Nature 363:67-69.

Smith, T.J., A.J. Noack, and S.M. Cosh. 1981. The effect of some herbicides on vesicular-arbuscular endophyte abundance in the soil and on infection of host roots. Pesticide Sci. 12:91-97.

South, D.B. 1981. Effects of selected herbicides on endomycorrhizal formation of sweetgum (Liquidambar styraciflua L.). 5th North Amer. Conf. Mycorrhizae, Laval Univ., Québec, Canada.

Steel, R.G.D. and J.H. Torrie. 1980. Principles and procedures of statistics: A Biometrical approach. 2nd ed. McGraw-Hill, New York.

Tennant, C. 1975. A test of a modified line intersect method of estimating root length. J. Ecol. 63:995-1001.

Trappe, J.M., R. Molina, and M. Castellano. 1984. Reactions of mycorrhizal fungi and mycorrhiza formation to pesticides. Annu. Rev. Phytopathol. 22:331-359 